\title{
Model Spatial Autoregressive (SAR) pada Tingkat Kemiskinan ( Studi Kasus : Provinsi Riau )
}

\author{
Rahmadeni $^{1}$ \\ ${ }^{1}$ Jurusan Matematika, Fakultas Sains dan Teknologi, UIN Sultan Syarif Kasim Riau \\ Jl. HR. Soebrantas No. 155 Simpang Baru, Panam, Pekanbaru, 28293 \\ Email: rahmadeni@uin-suska.ac.id
}

\begin{abstract}
ABSTRAK
Kemiskinan suatu daerah dipengaruhi oleh kemiskinan di daerah sekitarnya.Hal ini berdasarkan hukum geografi yang dikemukakan Tobler. Maka tujuan dari penelitian ini adalah Menentukan keterkaitan antara tingkat kemiskinan di suatu kabupaten dengan kabupaten lain yang berdekatan di Provinsi Riau dengan menggunakan model SAR. Model ini menunjukkan keterkaitan antara suatu daerah dengan daerahlain yang berdekatan dan juga menggambarkan seberapa besar pengaruh suatu variabel yang menjadi faktor penyebab meningkatnya kemiskinan terhadap angka kemiskinan tersebut.Berdasarkan Indeks Moran's diketahui Kabupaten yang yang berdekatan mempunyai nilai kemisikinan, IPM, tingkat pendidikan dan panjang jalan yang mirip dan cenderung berkelompok. model spatial faktor tingkat kemiskinan di Provinsi Riau lebih baik menggunakan model spatial error Model (SEM) dan Berdasarkan model SEM didapatkan peubah IPM, Pendidikan, PDRB dan pengangguran signifikan secara statistik sebab p-value $<0.05$, artinya faktor tersebut memberikan pengaruh yang kuat terhadap tingkat kemiskinan.
\end{abstract}

Kata kunci: Indeks Moran, kemiskinan, SAR, SEM.

\begin{abstract}
The poverty of an area is influenced by poverty in the surrounding area. This is based on the geographic law put forward by Tobler. So the purpose of this study is to determine the relationship between the level of poverty in a district and other nearby districts in Riau Province using the SAR model. This model shows the relationship between an area and other areas that are close to each other and also illustrates how much influence a variable that causes increased poverty has on the poverty rate. Based on the Moran's Index, it is known that adjacent districts have similar poverty, HDI, education levels and length of roads and tend to be in groups. The spatial model of the poverty level factors in Riau Province is better to use the spatial error model (SEM) and based on the SEM model, the HDI, education, GRDP and unemployment variables are statistically significant because the p-value is $<0.05$, meaning that these factors have a strong influence on the level of poverty
\end{abstract}

Keywords : Moran index, SAR, SEM, The Poverty.

\section{Pendahuluan}

Pengentasan kemiskanan dan kelaparan merupakan amanah pembangunan di era millenium ini berdasarkan dari kesapakatan 189 kepala negara dan perwakilan anggota Perserikatan bangsa bangsa (PBB) melalui millennium development goals (MDGs) yang disepakati untuk dijalankan tahun 2000. Persoalan kemiskinan merupakan satu diantara factor yang dapat menghambat pembangunan dinegara -negara didunia, tidak terkecuali di Negara berkembang seperti indoneisa. Dari 34 provinsi yang ada di indoneisa pada tahun 2017 (bulan Maret) provinsi Riau menempati prinkat ke 14 tingkat kemiskinan secara nasional. 
Berdasarkan dari laporan BPS Riau tentang perkembangan penduduk miskin di Provinsi Riau No. 04/01/Th.XXI, 2 Januari 2018 dapat di paparkan sebagai berikut.

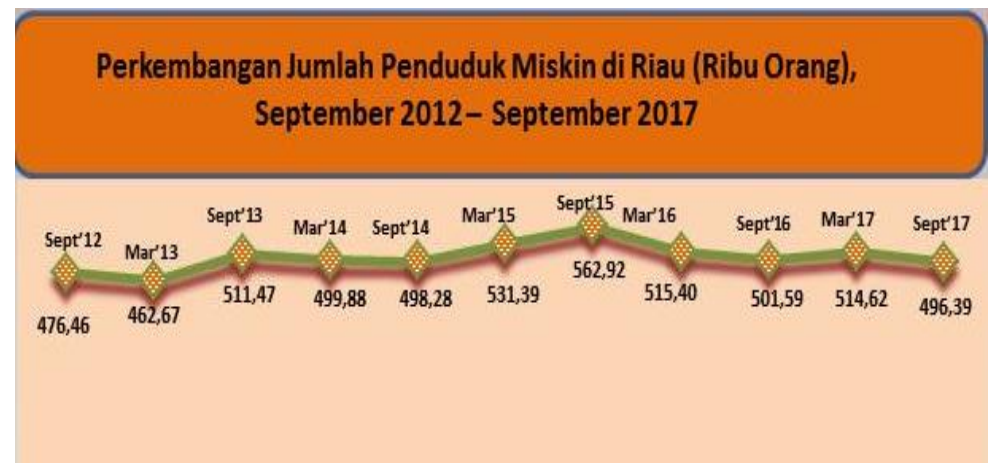

Gambar 1. Perkembangan Jumlah Penduduk Miskin di Riau

Kemiskinan suatu daerah dipengaruhi oleh kemiskinan di daerah sekitarnya.Standar tingkat hidup yang rendah sangat erat kaitannya sistem ekonomi di suatu daerah itu dan akan berpengaruh pada sistem ekonomi daerah-daerah disekitarnya karena tingkat kemiskinan pada kenyataannya dapat dipengaruhi oleh faktor daerah.

Menurut Syarifah [9] Mode regresi linear dapat digunakan untuk menggambarkan hubungan peubah bebas dengan peubah respon. Namun jika mempertimbangkan keterkaitan daerah atau lokasi , maka hubungan antara keduanya dapat digambarkan dengan menggunakan model Spatial Autoregressive (SAR). Berdasarkan hukum geografi yang dikemukakan Tobler (Tobler's first law of geography) dalam Schabenberger dan Gotway (2005), yang menyatakan "everything is related to everything else,but near things are more related than distant things". Segala sesuatu saling berhubungan satu dengan yang lainnya, tetapi sesuatu yang lebih dekat akan lebih berpengaruh daripada sesuatu yang jauh. Hukum Tobler digunakan sebagai pilar kajian analisis data spasial. Pada data spasial, seringkali pengamatan di suatu lokasi (space) bergantung pada pengamatan di lokasi lain yang berdekatan (neighboring).

Model SAR merupakan suatu model paling sederhana dari model spatial, ini dijelaskan oleh Anselin [1] dalam bukunya.Model ini diusulkan oleh Whittle pada tahun 1945. Dalam penelitiannya Ward dan Gledist [13] mengatakan bahwa Model SAR ditentukan berdasarkan nilai kedekatan suatu daerah dengan daerah tetangganya. Model SAR menunjukkan keterkaitan antara suatu daerah dengan daerahlain yang berdekatan.Model ini juga menggambarkan seberapa besar pengaruh suatu variabel yang menjadi faktor penyebab meningkatnya kemiskinan terhadap angka kemiskinan tersebut.

Pada penelitian Anggi dkk [2] mengatakan bahwa salah satu analisis yang digunakan untuk mengidentifikasi faktor-faktor yang berpengaruh terhadap tingkat kemiskinan dengan memperhatikan pengaruh daerah yaitu analisis Regresi Spasial. Dalam penelitian ini menghasilkan bahwa yang mempengaruhi kemiskinan secara signifikan adalah jumlah sarana pelayanan kesehatan, jumlah sarana sekolah, jumlah kepadatan penduduk, jumlah penduduk penyandang kesejahteraan sosial, dan jarak desa dari pusat Kabupaten.

Berdasarkan uraian di atas, pada penelitian ini penulis tertarik untuk menentukanbentuk model spasial dan faktor-faktor yang berpengaruh secara signifikan pada kasus tingkat kemiskinan di Provinsi Riau. 


\section{Metode dan Bahan Penelitian}

\section{Metodologi Penelitian}

Langkah-langkah dalam analisa data dari penelitian ini adalah:

a. Mendiskripsikan tingkat kemiskinan di provinsi Riau.

b. Melakukan pendugaan dan pengujian parameter model regresi klasik serta menguji asumsi galat (identik, independen dan berdistribusi normal).

c. Menentukan matriks pembobot spatialW.

d. Menguji efek spatial yaitu uji dependensi spatial dengan metode indeks Moran's.

e. Menentukan faktor-faktor yang mempengaruhi kejadian kemiskinan di kota Pekanbaru.

f. Menduga parameter untuk persamaan model SAR dan SEM serta menentukan model SAR dan SEM.

g. Menentukan model yang terbaik.

h. Menentukan peubah yang signifikan terhadap model

\section{Kemiskinan}

Kemiskinan merupakan suatu keadaan di mana terjadi ketidakmampuan untuk memenuhi kebutuhan ekonomi dasar seperti pangan (Makan), sandang ( pakaian), papan( Tempat tinggal), serta kesehatan dan pendidikan. Dikatan Penduduk miskin jika pendapatan dan pengeluaran penduduk di suatu wilaya tersebut dibwah standar garis kemiskinan.(Kementrian Keminfo, 2011 dikutip oleh Fima Anggadini, 2015).

\section{Daerah Riau}

Provinsi Riau terdiri dari 12 kabupaten yaitu :
a. Kabupaten Bengkalis dengan ibukota Bengkalis
b. Kabupaten Indragiri Hilir dengan ibukota Tembilahan
c. Kabupaten Indragiri Hulu dengan ibukota Rengat
d. Kabupaten Kampar dengan ibukota Bangkinang
e. Kabupaten Kuantan Singingi dengan ibukota Telukkuantan
f. Kabupaten Pelalawan dengan ibukota Pangkalankerinci
g. Kabupaten Rokan Hilir dengan ibukota Bagansiapiapi
h. Kabupaten Rokan Hulu dengan ibukota Pasirpengaraian
i. Kabupaten Siak dengan ibukota Sri Indrapura
j. Kabupaten Kep Meranti dengan ibukota Selatpanjang
k. Kota Dumai dengan ibukota Dumai
1. Kota Pekanbaru dengan ibukota Pekanbaru

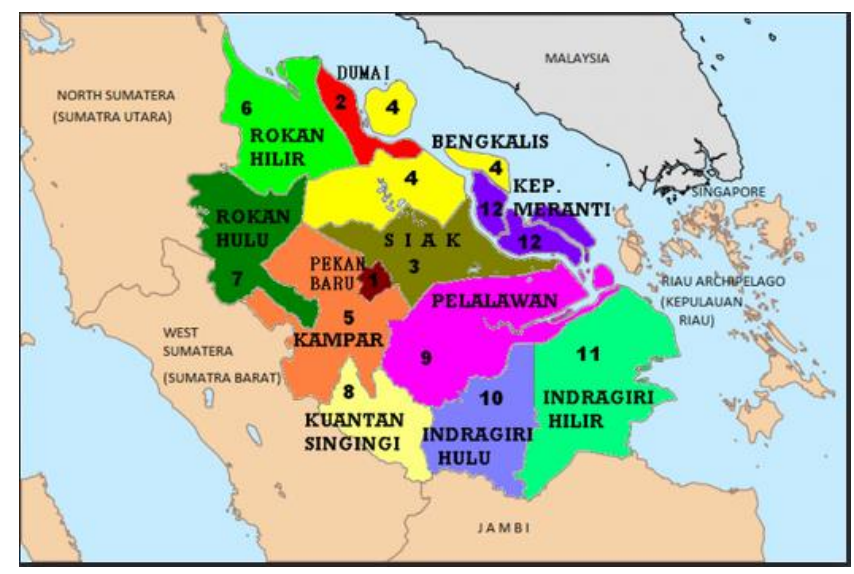

Gambar 2. Peta Daerah Riau

\section{Model Regresi Klasik}


Persamaan umum dari model regresi klasik menurutSyarifah [9] adalah :

$$
\boldsymbol{Y}=\boldsymbol{X} \boldsymbol{\beta}+\boldsymbol{\varepsilon} \quad \varepsilon \sim N\left(0, \sigma^{2} I\right)
$$

Bentuk matriks dari Persamaan 2.1 adalah sebagai berikut:

$$
\left[\begin{array}{c}
y_{1} \\
y_{2} \\
\vdots \\
y_{n}
\end{array}\right]=\left[\begin{array}{ccccc}
1 & x_{1.1} & x_{2.1} & \ldots & x_{p .1} \\
1 & x_{1.2} & x_{2.2} & \ldots & x_{p .2} \\
\vdots & \vdots & \vdots & \ldots & \vdots \\
1 & x_{1 . n} & x_{2 . n} & \cdots & x_{p . n}
\end{array}\right]\left[\begin{array}{c}
\beta_{0} \\
\beta_{1} \\
\vdots \\
\beta_{p}
\end{array}\right]+\left[\begin{array}{c}
\varepsilon_{1} \\
\varepsilon_{2} \\
\vdots \\
\varepsilon_{n}
\end{array}\right]
$$

Model regresi klasik untuk pendugaan suatu data diperoleh dari operasi matriks di atas, sehingga diperoleh model dugaan sebagai berikut:

$$
Y=\beta_{0}+\beta_{1} x_{1}+\cdots+\beta_{p} x_{p}
$$

dengan:

$Y$ : Matriks pengamatan untuk peubah terikat

$X$ : Matriks peubah bebas

$\beta$ : Parameter regresi

$\varepsilon$ : Residual acak

$n$ : Banyak daerah pengamatan

$p$ : Banyak variabel yang diamati

\section{Bentuk Umum Regresi Spatial}

Dalam Lesage [6], Bentuk umum model regresispatial adalah:

$\boldsymbol{Y}=\boldsymbol{\rho} W \boldsymbol{Y}+\boldsymbol{X \beta}+\boldsymbol{U}$

$\boldsymbol{U}=\lambda \boldsymbol{W U}+\varepsilon$

$$
\varepsilon \sim N\left(0, \sigma^{2} I\right)
$$

dengan:

$Y:$ Matriks Peubah terikat berukuran $n x 1$

$X$ : Matriks peubah bebas berukuran $(n x(p+1))$

$\beta$ : Koefisien parameter regresi spatial yang berukuran $p x 1$

$\rho:$ Koefisien autoregresi lag spatial

$\lambda$ : Koefisien autoregresi residual spatialdengan bernilai $|\lambda|<1$

$U$ : Vektor residual dengan asumsi terdapat autokorelasi yang berukuran $n x 1$

$\mathrm{W}$ :Pembobot matriks spatial dengan ukuran $n x n$, dimana $n$ merupakan daerah pengamatan.

Asumsi yang harus dipenuhi pada regresi spatialsama halnya dengan asumsi yang harus dipenuhi pada model regresi klasik. Asumsi yang harus dipenuhi adalah kehomogenan ragam, kenormalan residual dan tidak ada autokorelasi dari galat (Anselin, 2005).

\section{Indeks Moran's $(I)$}

Autokorelasi spasial sangat dibutuhkan dalam regresi spasial.Autokorelasi spasial ini merupakan ukuran dari korelasi atau hubungan antara pengamatan yang saling berdekatan.Banyak metode yang digunakan untuk mengukur autokorelasi spasial tersebt, salahsatunya dengan menggunakan Indeks Moran's .

Indeks Moran's mengukur hubungan satu peubah, misal $X\left(x_{i}\right.$ dan $\left.x_{j}\right)$ dimana $i \neq j, i=$ $1,2,3, \ldots, n, j=1,2,3, \ldots, n$ adalah indeks untuk daerah pengamatan. Rumus dari Indeks Moran's adalah Paradis [8] : 
dengan:

$$
I=\frac{n \sum_{i=1}^{n} \sum_{j \neq i}^{n} w_{i j}\left(x_{i-} \bar{x}\right)}{S_{0} \sum_{i=1}^{n}\left(x_{i}-\bar{x}\right)^{2}}\left(x_{j}-\bar{x}\right)
$$

$n$ : Banyaknya pengamatan (daerah)

$\bar{x}$ : Rata- rata dari variabel $x$

$w_{i j}$ : Elemen dari matriks pembobot

$S_{0}$ : Jumlah dari elemen matriks pembobot $\left(\sum_{i=1}^{n} \sum_{j \neq i}^{n} w_{i j}\right)$

Identifikasi menggunakan kriteria indeks $I$ adalah Paradis[8] :

jika $I>I_{0}$, mengindikasikan terjadinya autokorelasi positif

jika $I=I_{0}$, mengindikasikan tidak terjadinya autokorelasi

jika $I<I_{0}$, mengindikasikan terjadinya autokorelasi negatif.

$I_{0}$ adalah nilai harapan dari $I$ dengan rumus :

$$
E(I)=I_{0}=-1 / n-1
$$

\section{Model Spatial Autoregressive (SAR)}

Harviani mengatakan bahwa terjadinya ketergantungan nilai suatu pengamatan pada suatu daerah dengan daerah lainnya, dapat dimodelkan dengan model SAR. Sebagai contoh suatu tempat $i$ mempunyai korelasi dengan tempat $j$, maka nilai pengamatan pada tempat $i$ merupakan fungsi dari nilai pengamatan pada tempat $j$ dengan syarat $i \neq j$.

Bentuk umum dari model SAR adalah Anselin [1] :

$$
\begin{aligned}
& Y=\rho W Y+X \beta+\varepsilon \\
& \varepsilon \sim N\left(0, \sigma^{2} I\right)
\end{aligned}
$$

Parameter pada model ini diduga menggunakan metode Maksimum Log Likelihoo).Analisa pada model SAR melibatkan $\varepsilon_{i}$ yang merupakan galat spatial pada lokasi $i$ yang diasumsikan menyebar normal, homogen, identik dengan nilai tengah nol dan ragam $\sigma^{2}$.

\section{Matriks Pembobot Spatial (Matriks Contiguity)}

Matriks contiguity adalah matriks yang menggambarkan hubungan antar daerahLesage[6]. Matriks contiguity akan memberikan nilai 1 pada daerah yang berbatasan langsung dengan lokasi pengamatan dan sisanya diberikan nilai 0 atau dikosongkan.

Menurut Lesage [6] untuk menentukan bagaimana hubungan spatial (kedekatan) antara daerah pengamatan, dapat menggunakan berbagai metode dasar, antara lain meliputi:

\section{Queen contiguity}

Hubungan kedekatannya didasarkan pada langkah ratu pada papan catur.Daerah yang berhimpit ke arah kanan, kiri, atas, bawah, dan diagonal didefinisikan sebagai daerah yang saling berdekatan.

2. Rook contiguity

Hubungan spatial antar daerah pengamatan dapat ditentukan ke arah kanan, kiri, atas, dan bawah.Sedangkan arah diagonal tidak dapat ditentukan.

3. Bishop contiguity

Hubungan spatial antar daerah pengamatan hanya dapat ditentukan dalam arah diagonal saja.

\section{Hasil dan Pembahasan}

\section{Gambaran Umum Lokasi Penelitian}


Penelitian ini bertujuan untuk mendapatkan model spasial tingkat kemisikan di Provinsi Riau tahu 2018.Provinsi Riau secara georgrafis, geoekonomi dan geopolitik terletak pada jalur yang sangat strategis baik pada masa kini maupun masa yang akan datang terkait daerah jalur perdagangan Regional maupun Internasional di Kawasan ASEAN melalui kerjasama IMT-GT dan IMS-GT. Daerah Provinsi Riau mulai dari $01^{\circ} 05^{\prime} 00$ " Lintang Selatan sampai $02^{\circ} 25^{\prime} 00$ " Lintang Utara dan $100^{\circ} 00^{\prime} 00$ " hingga $105^{\circ} 05^{\prime} 00$ " Bujur Timur. Berikut ditampilkan peta provinsi Riau serta tingkat kemiskinan di tiap Kaupaten tahun 2018.

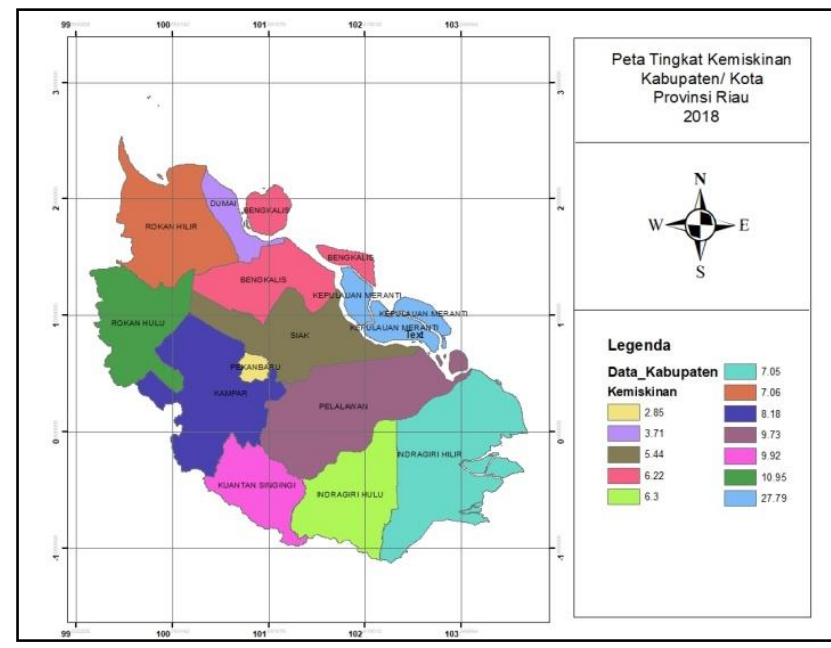

Gambar 3. Peta Tingkat Kemiskinan di Propinsi Riau

Pada tahun 2018, jumlah penduduk Provinsi Riau sebanyak 6.074.647 jiwa (DataKonsolidasi Semester II Tahun 2018 Ditjen Dukcapil Kemendagri RI) .Rata-rata kepadatan penduduk di Provinsi Riau 69.80 org $/ \mathrm{km} 2$ dengan Laju Pertumbuhan Penduduk sekitar $0.75 \%$ ).

\section{Model Spasial Kemsikinan di Provinsi Riau}

\subsection{Model Regresi Klasik}

Proses penyusunan model regresi diawali dengan melakukan regresi linier dengan menggunakan $\alpha=5 \%$. Berikut hasil output regresi klasik.

Tabel 1. Analisis Regresi Linier Berganda

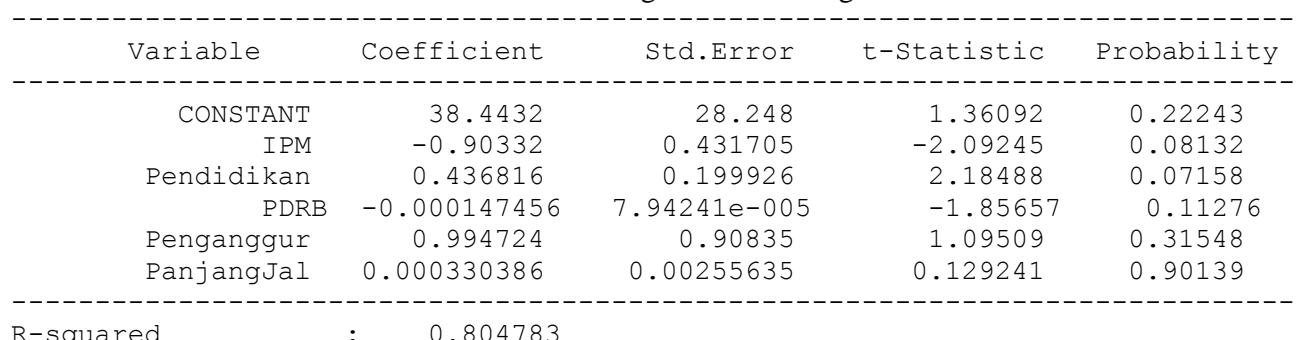

Berdasarkan tabel di atas diketahui bahwa tidak ada variabel bebas yang signifikan mempengaruhi tingkat kemiskinan. Selanjutnya akan di uji asumsi klasik untuj model ini. Pada regresi linear terdapat beberapa asumsi yang harus dipenuhi diantaranya normalitas dan heteroskedastisitas.

\subsection{Indeks Moran's}

Indeks Moran digunakan untuk Menguji efek spatial dengan menggunakan uji Indeks Morans I untuk melihat ada atau tidaknya otokorelasi spatial. Indeks moran 
menentukan autokorelasi suatu pengamatanvterhadap pengamatan yang sama di daerah lain yang berdekatan. Jika terdapatvautokorelasi berarti suatu pengamatan bisa dimasukkan kedalam model SAR, jika tidak terdapat autokorelasi berarti variabel tersebut tidak dimasukkan ke dalam model SAR.

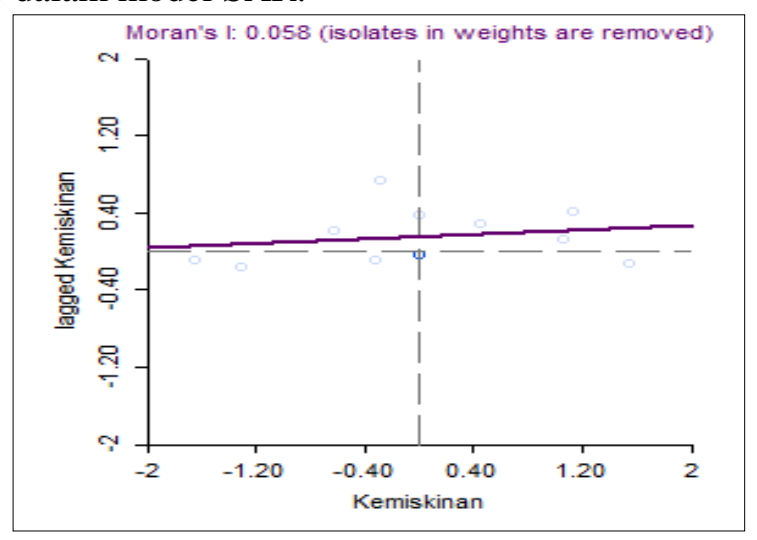

Gambar 4. Indeks Moran's Kemiskinan

Hasil indeks Moran I menunjukkan adanya autokorelasi spatial yang positif dengan nilai indeks Moran yaitu 0,058 artinya lokasi yang yang berdekatan mempunyai nilai kemisikinan yang mirip dan cenderung berkelompok.

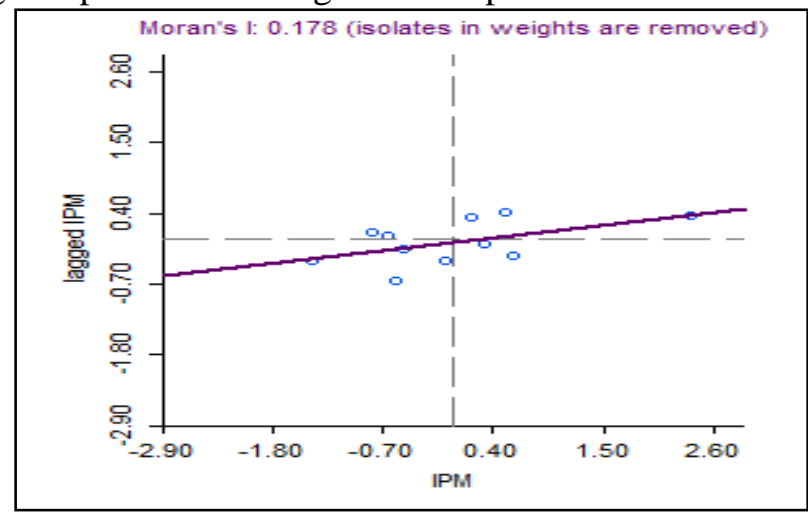

Gambar 5. Indeks Moran's IPM

Hasil indeks Moran I menunjukkan adanya autokorelasi spatial yang positif dengan nilai indeks Moran yaitu 0,178 artinya lokasi yang yang berdekatan mempunyai nilai IPM yang mirip dan cenderung berkelompok.

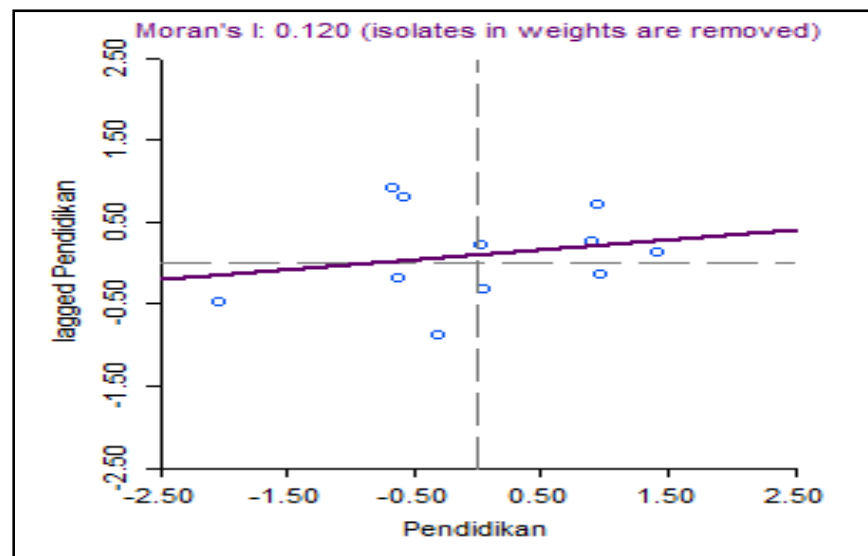

Gambar 6. Indeks Moran's Pendidikan 
Hasil indeks Moran I menunjukkan adanya autokorelasi spatial yang positif dengan nilai indeks Moran yaitu 0,120 artinya lokasi yang yang berdekatan mempunyai nilai tingkat pendidikan yang mirip dan cenderung berkelompok.

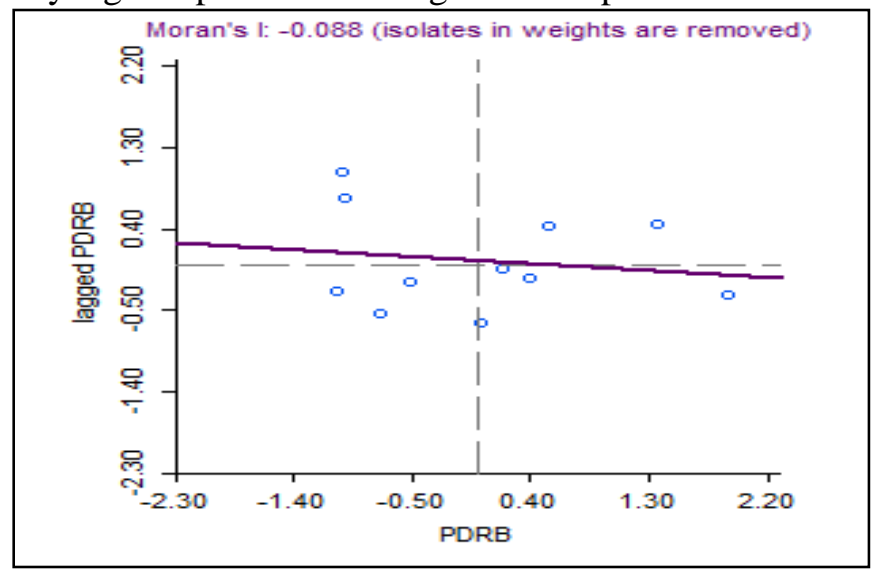

Gambar 7.Indeks Moran’s PDRB

Hasil indeks Moran I menunjukkan adanya autokorelasi spatial yang negatif dengan nilai indeks Moran yaitu -0,088 artinya tingkat PDRB yang cenderung menyebar.

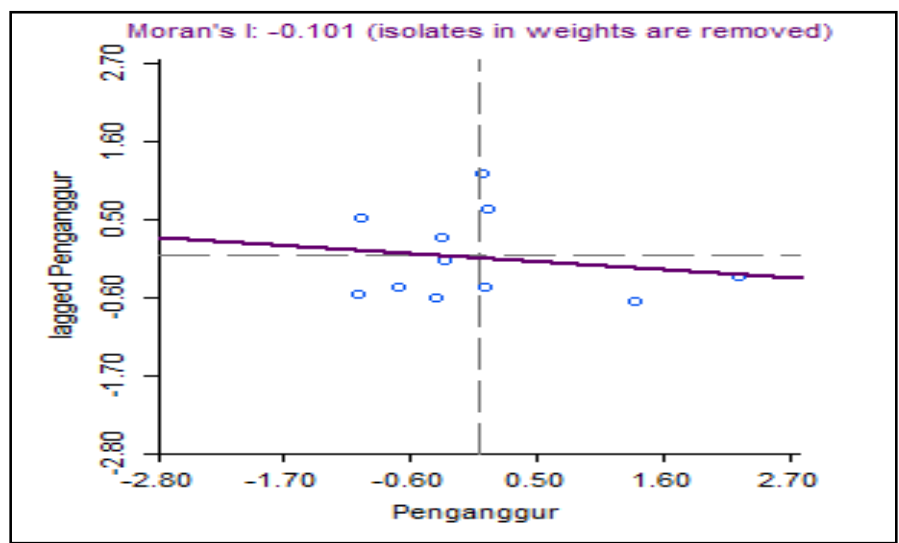

Gambar 8. Indeks Moran's Pengangguran

Hasil indeks Moran I menunjukkan adanya autokorelasi spatial yang negatif dengan nilai indeks Moran yaitu -0,101 artinya tingkat pengangguran yang cenderung menyebar.

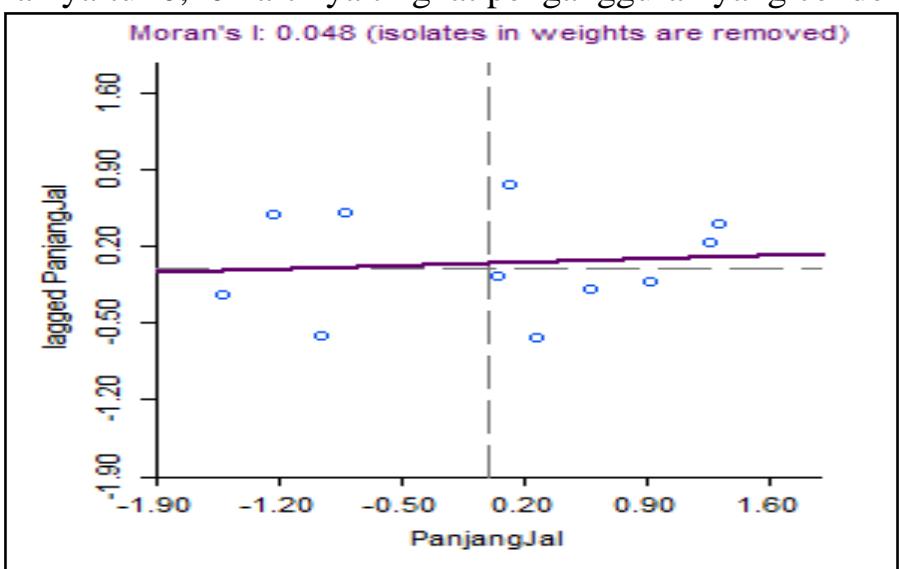

Gambar 9. Indeks Moran's Panjang Jalan 
Hasil indeks Moran I menunjukkan adanya autokorelasi spatial yang positif dengan nilai indeks Moran yaitu 0,048 artinya Panjang jalan pada lokasi yang berdekatan cenderung mengelompok.

\subsection{Penentuan Model Regresi Spatial}

Untuk menentukan pemodelan spatial, perlu dilakukan uji Lagrange Multiplier (LM) sebagai identifikasi awal. Apabila data yang diperoleh menghasilkan dependensi lag maka data dimodelkan dengan Spatial Autoregresive Model (SAR), namun apabila data menghasilkan dependensi error maka data dimodelkan dengan Spatial Error Model (SEM). Berikut tabel yang menunjukkan hasil uji Lagrange Multiplier (LM).

Tabel 2.ujiLagrange Multiplier

\begin{tabular}{|c|c|c|c|}
\hline TEST & $\mathrm{MI} / \mathrm{DF}$ & VALUE & $\mathrm{PROB}$ \\
\hline Moran's I (error) & 0.1472 & 1.3940 & 0.16331 \\
\hline Lagrange Multiplier (lag) & 1 & 1.4995 & 0.22074 \\
\hline Robust LM (lag) & 1 & 9.5638 & 0.00198 \\
\hline Lagrange Multiplier (error) & 1 & 0.4628 & 0.49630 \\
\hline Robust LM (error) & 1 & 8.5271 & 0.00350 \\
\hline Lagrange Multiplier (SARMA) & 2 & 10.0266 & 0.00665 \\
\hline
\end{tabular}

Berdasarkan tabel di atas diketahui nilai p value LM lag (0.22074) lebih kecil dari LM error (0.49630) dan nilai probabilitas Robust LM (lag) signifikan yaitu 0.00198 dan nilai rebust LM (error) juga signifikan dengan nilai $\mathrm{p}=$ 0.00350 (pada $\alpha=0,1$ ). Hal ini dapat disimpulkan bahwa model spatial menggunakan spatial lag (spatial autoregressive model/SAR) maupun spatial error (spatial error model) bisa digunakan.

\subsection{Model Regresi Spasial pada Tingkat Kemiskinan di Provinsi Riau}

Hasil uji efek ketergantungan spatial menunjukkan bahwa model spatial lag dan spatial error dapat digunakan. Hasil pemodelan dari dua model akan dibandingkan manakah model yang terbaik dengan melihat nilai koefisien determinan, nilai Akaike info criterion (AIC) dan Schwarz criterion (SC) dari masing-masing pemodelan. Berikut ini adalah Model Regresi Spasial Pada Tingkat Kemiskinan Di Provinsi Riau menggunakan dua model di atas:

\subsubsection{Hasil Pemodelan Regresi Spatial Lag (SAR)}

Variabel yang memiliki pengaruh spatial terhadap Tingkat Kemiskinan Di Provinsi Riau dengan menggunakan analisis regresi spatial lag yaitu IPM, Pendidikan, Pengangguran, PDRB dan panjang jalan. Berikut hasil uji regresi spatial lag (SAR) tersaji pada Tabel berikut.

Tabel 3. Uji Regresi Spatial Lag (SAR)

\begin{tabular}{|c|c|c|c|c|c|}
\hline & Variable & Coefficient & Std.Error & z-value & Probability \\
\hline & --------------1 & ----ー-ー--ー- & ------ & -------- & 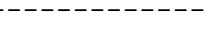 \\
\hline & W_Kemiskinan & -0.978762 & 0.263158 & -3.71929 & 0.00020 \\
\hline & - CONSTANT & 50.6995 & 14.8996 & 3.40274 & 0.00067 \\
\hline & IPM & -0.835144 & 0.22337 & -3.73884 & 0.00018 \\
\hline & Pendidikan & 0.280908 & 0.123494 & 2.27467 & 0.02293 \\
\hline PDRB & $-9.36912 e-005$ & $4.1333 e-005$ & -2.26674 & 0.02341 & \\
\hline & Penganggur & 0.555129 & 0.463365 & 1.19804 & 0.23090 \\
\hline & PanjangJal & 0.00132268 & 0.00130728 & 1.01178 & 0.31165 \\
\hline
\end{tabular}

Model spasial Lag berarti model dibentuk dengan melibatkan peubah lag spasial dependen. Model yang didapatkan adalah sebagai berikut: 


$$
\begin{aligned}
Y= & 50.699-0.979 W_{y}-0.835 X_{1}+0.281 X_{2}-9.369 \times 10^{-5} X_{3}+0.555 X_{4}+0.001 \\
& X_{5}
\end{aligned}
$$

Penentuan variable predictor pada model SAR dapat diuji secara formal dengan menggunakan uji signifikansi dengan hipotesis sebagai berikut:

\section{$\mathrm{H}_{0}: \theta=0$ (Parameter tidak siginifikan) $; \mathrm{H}_{0}: \theta \neq 0$ (Parameter signifikan)}

Dari daftar koefisien pada output diatas dapat disimpulkan bahwa koefisien autoregresif pada tingkat kemiskinan untuk peubah IPM, Pendidikan, PDRB signifikan secara statistik sebab $p$-value $<0.05$, artinya factor tersebut memberikan pengaruh yang kuat terhadap tingkat kemiskinan. Sedangkan faktor lainnya pengangguran dan jumlah jalan tidak mempengaruhi, sebab nilai $p$-value variabel tersebut $>0.05$.Jika dilihat spasial lag-nya, dapat dikatakan bahwa faktor spasial IPM, Pendidikan dan PDRB mempengaruhi tingkat kemiskinan di tiap kabupaten di Provinsi Riau. Daerah yang mempunyai faktor spasial lokasi yang berdekatan (baik secara astronomis dan geografis) akan mempengaruhi tingkat kemiskinan. nilai $\mathrm{R}$ square sebesar 0,8985 menunjukkan tingkat kemiskinan di Provinsi Riau mampu dijelaskan oleh variabel bebas di atas sebesar $89,85 \%$.

\subsubsection{Hasil Pemodelan Regresi Spatial Error Model (SEM)}

Variabel yang memiliki pengaruh spatial terhadap Tingkat Kemiskinan Di Provinsi Riau dengan menggunakan analisis regresi spatial lag yaitu IPM, Pendidikan, Pengangguran, PDRB dan panjang jalan. Berikut hasil uji regresi spatial error model (SEM) tersaji pada tabel berikut:

Tabel 4. Uji Regresi Spatial Error Model (SEM)

$\begin{array}{rrrrr}\text { Variable } & \text { Coefficient } & \text { Std.Error } & \text { z-value } & \text { Probability } \\ \text { CONSTANT } & 67.6547 & 10.9045 & 6.20429 & 0.00000 \\ \text { IPM } & -0.740545 & 0.153057 & -4.83834 & 0.00000 \\ \text { Pendidikan } & 0.0234168 & 0.0806674 & 0.290288 & 0.77160 \\ \text { PDRB -6.50375e-005 } & 3.09468 e-005 & -2.10159 & 0.03559 & 0.00674 \\ \text { Penganggur } & 0.807293 & 0.29798 & 2.70922 & 0.11890 \\ \text { PanjangJal } & 0.00137303 & 0.000880491 & 1.55939 & 0.00000 \\ \text { LAMBDA } & 0.980451 & 0.0140503 & 69.7817 & \\ \text { R-squared } & : & 0.954947 & \end{array}$

Model spasial Lag berarti model dibentuk dengan melibatkan peubah dependen. Model yang didapatkan adalah sebagai berikut:

$$
\begin{aligned}
\mathrm{Y}= & 67.655-0.980 \mathrm{~W}_{\mathrm{y}}-0.741 \mathrm{X}_{1}+0.023 \mathrm{X}_{2}-6.504 \times 10^{-5} \mathrm{X}_{3}+0.807 \mathrm{X}_{4}+0.001 \\
& \mathrm{X}_{5}
\end{aligned}
$$

Penentuan variable predictor pada model SEM dapat diuji secara formal dengan menggunakan uji signifikansi dengan hipotesis sebagai berikut:

$\mathrm{H}_{0}: \theta=0$ (Parameter tidak siginifikan); $\mathrm{H}_{0}: \theta \neq 0$ (Parameter signifikan)

Dari daftar koefisien pada output diatas dapat disimpulkan bahwa koefisien autoregresif pada tingkat kemiskinan untuk peubah IPM, Pendidikan, PDRB dan pengangguran signifikan secara statistik sebab $p$-value $<0.05$, artinya factor tersebut memberikan pengaruh yang kuat terhadap tingkat kemiskinan. Sedangkan faktor lainnya Pendidikan dan Panjang jalan tidak mempengaruhi, sebab nilai $p$-value variabel tersebut $>$ 0.05.Jika dilihat spasial lag-nya, dapat dikatakan bahwa faktor spasial IPM, pengangguran dan PDRB mempengaruhi tingkat kemiskinan di tiap kabupaten di 
Provinsi Riau. Daerah yang mempunyai faktor spasial lokasi yang berdekatan (baik secara astronomis dan geografis) akan mempengaruhi tingkat kemiskinan. nilai $\mathrm{R}$ square sebesar 0,9549 menunjukkan tingkat kemiskinan di Provinsi Riau mampu dijelaskan oleh variabel bebas di atas sebesar $95,49 \%$.

\subsection{Perbandingan Model SAR dan SEM pada Tingkat Kemiskinan di Provinsi Riau}

Setelah diketahui hasil uji masing-masing model baik model regresi spatial lag (SAR) maupun model spatial error (SEM) maka perlu dibandingkan keduanya untuk mendapatkan model yang terbaik. Berikut tabel yang menunjukkan perbandingan SAR dan model SEM:

Tabel 5.Perbandingan Model Spatial Lag dan Spatial Error Tingkat Kemiskinan di Provinsi Riau

\begin{tabular}{|l|l|l|}
\hline Model & AIC & SC \\
\hline Spatial lag (SAR) & 67.3548 & 70.7492 \\
\hline Spatial error (SEM) & 61.4775 & 64.387 \\
\hline
\end{tabular}

Pada Tabel 5 dapat dilihat bahwa nilai Akaike info criterion (AIC) pada model SEM lebih kecil dari AIC pada model SAR. Begitu pula dengan nilai Schwarz criterion (SC) dimana nilai SC pada model SEM lebih kecil dari regresi klasik SAR.Sehingga dapat disimpulkan bahwa model spatial faktor tingkat kemiskinan di Provinsi Riau lebih baik menggunakan model spatial error (SEM).

\section{Kesimpulan}

Berdasarakan hasil analisis data dan penjelasan pada bab sebelumnya maka dapat disimpulkan:

1. Berdasarkan Indeks Moran's diketahui Kabupaten yang yang berdekatan mempunyai nilai kemisikinan, IPM, tingkat pendidikan dan Panjang jalan yang mirip dan cenderung berkelompok.

2. Berdasarkan Indeks Moran's diketahui tingkat PDRB dan penganguran cenderung menyebar.

3. Berdasarkan Tabel di atas diketahui nilai pvalue LM lag, LM error, Robust LM (lag) dan nilai robust LM (error) dapat disimpulkan bahwa model spatial menggunakan spatial lag (spatial autoregressive model/SAR) maupun spatial error (Spatial Error Model) bisa digunakan.

4. Berdasarkan analisis disimpulkan bahwa model spatial faktor tingkat kemiskinan di Provinsi Riau lebih baik menggunakan model spatial error (SEM)

Berdasarkan model SEM didapatkan peubah IPM, Pendidikan, PDRB dan pengangguran signifikan secara statistik sebab $p$-value $<0.05$, artinya faktor tersebut memberikan pengaruh yang kuat terhadap tingkat kemiskinan.

\section{DaftarPustaka}

[1] Anselin,L., Spatial Econometrics, University of Illions, Urbana-Champaign, 2005.

[2] Anggi ,A.P., Sanusi W dan Sukarna, Model Regresi Spasial dan Aplikasinya pada Kasus Tingkat Kemiskinan Kabupaten Soppeng, Indonesian Journal of Fundamental Sciences (IJFS), 4 (2 ), 2018, 102-109.

[3] Anselin,L., Spatial Regression Analysis in R. University of Illions, UrbanaChampaign, 2005.

[4] Arisanti, R.,Model Regresi Spasial untuk Deteksi Faktor-Faktor Kemiskinan di Provinsi Jawa Timur, Tesis, Sekolah Pascasarjana Institut Pertanian Bogor, 2011.

[5] Djuraidah, A, dkk., Regresi spasial untuk Menentukan Faktor-faktor Kemiskinan di Provinsi Jawa Timur. Statistika, 12 (1), 2012 
[6] Lesage, J.P, Spatial Econometrics, Department of Economics University of Toledo, 1998.

[7] Nakhapakorn, Kanchana andJirajohnkoll.,Temporal and Spatial Autocorrelation Statistics of Dengue Fever, Dengue Bulletin - Volume 30, 2006.

[8] Paradis, Emanuel, Moran's Autocorrelation, 2010.

[9] Syarifah, D.P., Ronald, J and Chowanda A., Spatial Autoregressive model for avarege expenditur of Papua Province,Proceedings of the 4st International Conference on Computer Science and Computational Intelligence, 2019,527-542.

[10] Sembiring, R.K., Analisis Regresi, Penerbit ITB, Bandung, 1995.

[11] Supranto, J., Ekonometri. Ghalia Indonesia, Bogor, 2005.

[12] Supranto, J., Analisis Multivariat Arti \& Interpretasi, PT Rineka Cipta, Jakarta, 2004. 